\title{
Leading Causes of Cancer Mortality — Caribbean Region, 2003-2013
}

\author{
Hilda Razzaghi, PhD 1,2; Sarah Quesnel-Crooks, MSc ${ }^{3}$; Recinda Sherman, $\mathrm{PhD}^{4}$; Rachael Joseph, VMD ${ }^{1,2}$; Betsy Kohler, MPH ${ }^{4}$; Glennis Andall- \\ Brereton, $\mathrm{PhD}^{3}$; Marsha A. Ivey, $\mathrm{MSc}^{3}$; Brenda K. Edwards, $\mathrm{PhD}^{5}$; Les Mery, MSc ${ }^{6}$; Vilma Gawryszewski, MD ${ }^{7}$; Mona Saraiya, MD ${ }^{1,2}$
}

Cancer is one of the leading causes of deaths worldwide (1); in 2012, an estimated $65 \%$ of all cancer deaths occurred in the less developed regions of the world (2). In the Caribbean region, cancer is the second leading cause of mortality, with an estimated 87,430 cancer-related deaths reported in 2012 (3). The Pan American Health Organization defines the Caribbean region as a group of 27 countries that vary in size, geography, resources, and surveillance systems. ${ }^{*} \mathrm{CDC}$ calculated site- and sex-specific proportions of cancer deaths and age-standardized mortality rates (ASMR) for 21 English- and Dutch-speaking Caribbean countries, the United States, and two U.S. territories (Puerto Rico and the U.S. Virgin Islands [USVI]), using the most recent 5 years of mortality data available from each jurisdiction during 2003-2013. The selection of years varied by availability of the data from the countries and territories in 2015. ASMR for all cancers combined ranged from 46.1 to 139.3 per 100,000 . Among males, prostate cancers were the leading cause of cancer deaths, followed by lung cancers; the percentage of cancer deaths attributable to prostate cancer ranged from $18.4 \%$ in Suriname to $47.4 \%$ in Dominica, and the percentage of cancer deaths attributable to lung cancer ranged from 5.6\% in Barbados to 24.4\% in Bermuda. Among females, breast cancer was the most common cause of cancer deaths, ranging from $14.0 \%$ of cancer deaths in Belize to $29.7 \%$ in the Cayman Islands, followed by cervical cancer. Several of the leading causes of cancer deaths in the Caribbean can be reduced through primary and secondary preventions, including prevention of exposure to risk factors, screening, early detection, and timely and effective treatment.

Among the 21 countries $^{\dagger}$ that submitted mortality data to the Caribbean Public Health Agency during 2003-2013, the proportions of all cancer deaths and ASMR by cancer site and sex were calculated for the most recent 5 years of available data for 21 English- and Dutch-speaking Caribbean countries. ASMRs are reported for the leading 10 causes of cancer deaths determined by the proportions of all cancer deaths. Calculations were completed using SEER*Stat software (4)

\footnotetext{
* Pan American Health Organization countries and centers. http://www.paho. $\mathrm{org} / \mathrm{hq} / \mathrm{index}$.php?option=com_wrapper\&Itemid=2005.

$\dagger$ Anguilla, Antigua and Barbuda, Aruba, The Bahamas, Barbados, Belize, Bermuda, Bonaire, St Eustatius and Saba (BES), British Virgin Islands, Cayman Islands, Curacao, Dominica, Grenada, Guyana, Haiti, Jamaica, Montserrat, St. Lucia, St. Kitts and Nevis, St. Maarten, St. Vincent and the Grenadines, Suriname, Trinidad and Tobago, and Turks and Caicos Islands
}

and age-standardized to the Segi World Standard population (in millions) $(5,6)$. Population data from the 21 Caribbean Public Health Agency countries, based on census data, were not available from any country for all 5 years; in these cases, the most recent year of available data (i.e., census or estimates) was used to populate subsequent years with missing population data. Proportions and ASMRs are not presented where there were fewer than six cases and were not included when determining ASMR ranges. Because data were not available from all contributing countries for any single year during the study period, regional cancer-specific mortality rates could not be calculated. Using the same criteria, ASMR for USVI, Puerto Rico, and the United States were calculated to provide a more comprehensive picture of the region, using mortality data from CDC's National Center for Health Statistics.

The total number of cancer deaths among males and females (International Classification of Diseases, 10th revision [ICD-10]: C00-C97) reported by countries and territories ranged from 32 in Turks and Caicos to 26,135 in Puerto Rico (Table 1). ASMR for all sites (all cancer-related deaths combined) ranged from 46.1 per 100,000 in Turks and Caicos to 139.3 per 100,000 in St. Kitts and Nevis. Among the 21 English- and Dutch-speaking Caribbean countries, prostate cancer was the most common cause of cancer-related deaths among males in 20 of the countries, accounting for $18.4 \%-47.4 \%$ of cancer deaths, followed by cancer of the lung and bronchus (lung), which accounted for $5.6 \%-24.4 \%$ of cancer deaths (Table 1 ) (supplemental figures https://stacks.cdc.gov/view/cdc/42948; https://stacks.cdc.gov/view/cdc/42949). Among females, breast cancer was the most common cause of cancer deaths in 16 of the 18 countries for which data were reported, accounting for $14.0 \%-29.7 \%$ of cancer deaths, followed by cervical cancer, which accounted for $4.5 \%-18.2 \%$ of cancer deaths (Table 1) (supplemental figures https://stacks.cdc.gov/view/ cdc/42950; https://stacks.cdc.gov/view/cdc/42951). For both sexes, cancer of the colon and rectum (colorectal) was the third most common cause of cancer death (Table 1).

Among males, ASMR for prostate cancer ranged from 15.1 to 74.1 per 100,000 standard population, for lung cancer, from 4.6 to 34.0 per 100,000 , and for colorectal cancer, from 4.9 to 18.1 per 100,000 (Table 2). Among females, ASMR for breast cancer ranged from 10.0 to 27.3 per 100,000 , for cervical cancer, from 4.1 to 15.5 per 100,000 , and for colorectal cancer, from 3.7 to 13.9 per 100,000 (Table 2). 
TABLE 1. Top 10 causes of cancer deaths, by sex, based on 5-year cumulative proportion - 21 countries in the Caribbean region, United States, U.S. Virgin Islands, and Puerto Rico, 2003-2013*

\begin{tabular}{|c|c|c|c|c|c|c|c|c|c|c|c|}
\hline & $\begin{array}{l}\text { Colon/ } \\
\text { Rectum }\end{array}$ & Esophagus & Leukemia & $\begin{array}{c}\text { Liver/ } \\
\text { Intra- } \\
\text { hepatic bile } \\
\text { duct } \\
\end{array}$ & $\begin{array}{c}\text { Lung/ } \\
\text { Bronchus }\end{array}$ & $\begin{array}{c}\text { Non- } \\
\text { Hodgkin } \\
\text { lymphoma }\end{array}$ & $\begin{array}{c}\text { Oral cavity/ } \\
\text { Pharynx }\end{array}$ & Pancreas & Prostate & Stomach & All sites ${ }^{\dagger}$ \\
\hline Males & No. (\%) & No. (\%) & No. $(\%)$ & No. (\%) & No. (\%) & No. (\%) & No. (\%) & No. (\%) & No. (\%) & No. (\%) & No. (\%) \\
\hline \multicolumn{12}{|c|}{ Caribbean countries } \\
\hline Anguilla§ & NR & NR & NR & NR & NR & NR & NR & NR & $25(44.6)$ & NR & $56(100)$ \\
\hline $\begin{array}{l}\text { Antigua and } \\
\text { Barbuda }\end{array}$ & $20(8.1)$ & $6(2.4)$ & NR & $12(4.9)$ & $23(9.3)$ & $6(2.4)$ & $9(3.7)$ & NR & $110(44.7)$ & $9(3.7)$ & $246(100)$ \\
\hline Aruba $^{\S}$ & $34(9.9)$ & $12(3.5)$ & $9(2.6)$ & $19(5.5)$ & $72(20.9)$ & $13(3.8)$ & $12(3.5)$ & $12(3.5)$ & $74(21.5)$ & $30(5.8)$ & 344 (100) \\
\hline Bahamas" & $96(10.5)$ & $35(3.8)$ & $30(3.3)$ & $26(2.8)$ & $114(12.5)$ & $21(2.3)$ & $26(2.8)$ & 31 (3.4) & $247(27.1)$ & $53(5.8)$ & 912 (100) \\
\hline Barbados & $151(11.6)$ & $28(2.1)$ & $31(2.4)$ & $17(1.3)$ & $73(5.6)$ & $22(1.7)$ & $48(3.7)$ & $51(3.9)$ & $507(38.9)$ & $60(4.6)$ & $1,302(100)$ \\
\hline Belize $^{\S}$ & $26(6.2)$ & $9(2.1)$ & $21(4.9)$ & $38(8.9)$ & $62(14.6)$ & $12(2.8)$ & $6(1.4)$ & $13(3.1)$ & $106(24.9)$ & $37(8.7)$ & $425(100)$ \\
\hline Bermuda** & $29(9.4)$ & $9(2.9)$ & $11(3.6)$ & $9(2.9)$ & 75 (24.4) & $10(3.3)$ & $10(3.3)$ & $18(5.9)$ & $62(20.2)$ & $11(3.6)$ & $307(100)$ \\
\hline $\begin{array}{l}\text { British Virgin } \\
\text { Islands }{ }^{\dagger \dagger}\end{array}$ & $8(13.1)$ & NR & $N R$ & NR & $6(9.8)$ & NR & NR & NR & $13(21.3)$ & NR & $61(100)$ \\
\hline Cayman Islands ${ }^{\S}$ & $8(7.5)$ & NR & NR & NR & $23(21.7)$ & NR & NR & NR & $28(26.4)$ & NR & $106(100)$ \\
\hline Curacao $^{\S \S}$ & $81(11.0)$ & $37(5.0)$ & $11(1.5)$ & $18(2.4)$ & $142(19.3)$ & $14(1.9)$ & $21(2.8)$ & $34(4.6)$ & $191(25.9)$ & $38(5.2)$ & 737 (100) \\
\hline Dominica & $18(5.0)$ & $6(1.7)$ & NR & $10(2.9)$ & $26(7.2)$ & $9(2.5)$ & $9(2.5)$ & $20(5.6)$ & $170(47.4)$ & $32(8.9)$ & $359(100)$ \\
\hline Grenada§ & $30(6.5)$ & $20(4.3)$ & NR & $10(2.1)$ & $36(7.7)$ & $27(5.8)$ & $18(3.9)$ & $17(3.7)$ & $193(41.5)$ & $22(4.7)$ & 465 (100) \\
\hline Guyana? & $77(7.7)$ & $19(1.9)$ & $43(4.3)$ & $71(7.1)$ & $65(6.5)$ & $23(2.3)$ & $32(3.2)$ & $42(4.2)$ & $342(34.0)$ & $52(5.2)$ & $1,005(100)$ \\
\hline Jamaica? & $624(7.3)$ & $179(2.1)$ & 247 (2.9) & $228(2.7)$ & $1,466(17.1)$ & $252(2.9)$ & $171(2.0)$ & $204(2.4)$ & $2,919(34.0)$ & $587(6.8)$ & $8,576(100)$ \\
\hline Montserrat & NR & NR & NR & NR & NR & NR & NR & NR & $8(33.3)$ & NR & $24(100)$ \\
\hline $\begin{array}{l}\text { St. Kitts and } \\
\text { Nevis }^{\S}\end{array}$ & $10(6.7)$ & NR & NR & $15(10.1)$ & $10(6.7)$ & $4(2.7)$ & NR & NR & $69(46.3)$ & NR & 149 (100) \\
\hline St. Lucia§ & $25(5.2)$ & $17(3.6)$ & $17(3.6)$ & $11(2.3)$ & 55 (11.5) & $14(2.9)$ & $16(3.3)$ & $19(4.0)$ & $152(31.8)$ & $47(9.8)$ & $478(100)$ \\
\hline $\begin{array}{l}\text { St. Vincent } \\
\text { and the } \\
\text { Grenadines }\end{array}$ & $27(7.4)$ & $6(1.6)$ & $12(3.3)$ & $16(4.4)$ & $21(5.8)$ & $13(3.6)$ & $12(3.3)$ & $17(4.7)$ & $162(44.5)$ & $20(5.5)$ & $364(100)$ \\
\hline Suriname $\mathrm{S}^{\S}$ & 124 (12.9) & NR & $30(3.1)$ & $75(7.8)$ & $151(15.7)$ & $32(3.3)$ & $33(3.4)$ & $45(4.7)$ & 177 (18.4) & $51(5.3)$ & $963(100)$ \\
\hline $\begin{array}{c}\text { Trinidad and } \\
\text { Tobago }{ }^{* * *}\end{array}$ & 389 (10.5) & $58(1.6)$ & $122(3.3)$ & $84(2.3)$ & 470 (12.7) & $115(3.1)$ & $98(2.6)$ & $190(5.1)$ & $1,302(35.1)$ & $157(4.2)$ & $3,706(100)$ \\
\hline $\begin{array}{l}\text { Turks and Caicos } \\
\text { Islands*** }\end{array}$ & NR & NR & NR & NR & NR & NR & NR & NR & NR & NR & $15(100)$ \\
\hline $\begin{array}{l}\text { Total for the } \\
\text { Caribbean } \\
\text { countries }\end{array}$ & $1,785(8.7)$ & $455(2.2)$ & 604 (2.9) & $668(3.2)$ & $2,897(14.1)$ & $591(2.9)$ & $533(2.6)$ & $726(3.5)$ & $6,861(33.3)$ & 1,209 (5.9) & $20,600(100)$ \\
\hline
\end{tabular}

United States and U.S Caribbean territories

United States $^{\S} \quad 134,482(9.0) \quad 56,503(3.8) \quad 65,373(4.4) \quad 69,183(4.6) \quad 437,358(29.1) \quad 55,783(3.7) \quad 29,161(1.9) \quad 92,683(6.2) \quad 140,333(9.3) \quad 33,258(2.2) \quad 1,500,932(100)$

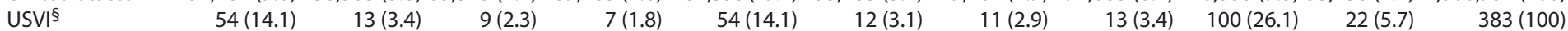

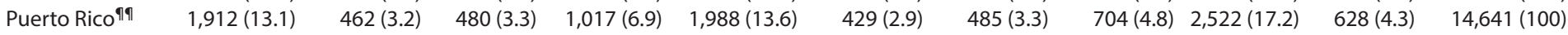

See table footnotes on next page.

The proportion of unknown/missing/invalid cause of death codes reported by the 21 English- and Dutch-speaking Caribbean countries ranged from $2.3 \%$ to $12.9 \%$, with three (14\%) countries reporting $>10 \%$ unknown/missing/invalid cause of death codes, compared with USVI and Puerto Rico, where these percentages were $<1 \%$. In addition, 5.3\%-15.6\% of cancers were coded as "miscellaneous malignant cancer" in the Caribbean countries.

Although data on pediatric cancers (cancers in persons aged $<20$ years) are not presented, $16(76 \%)$ of the 21 countries and Puerto Rico reported pediatric cancers and ASMR in countries with $\geq 6$ reported cases (11 of 16 countries) ranged from 2.9 per 100,000 in Curacao to 8.8 per 100,000 in Grenada, and 4.2 per 100,000 in Puerto Rico. The majority of pediatric cancer deaths were attributable to leukemia, brain and other nervous system cancers, and cancers of the bones and joints.

Cancer was the leading cause of death in approximately half of the countries when compared with heart disease alone; when compared with all cardiovascular disease (ICD-10: I00-I99), including heart disease, hypertension without heart disease, cerebrovascular diseases, atherosclerosis, aortic aneurysm and dissection, and other diseases of arteries combined, cancer was the second leading cause of death in all countries. There is wide variation in cancer-specific mortality rates within the Englishand Dutch-speaking Caribbean region, USVI, and Puerto Rico; however, prostate and breast cancers were consistently the leading causes of cancer-related deaths among males and females, respectively. When compared with the United States, 
TABLE 1. (Continued) Top 10 causes of cancer deaths, by sex, based on 5-year cumulative proportion - 21 countries in the Caribbean region, United States, U.S. Virgin Islands, and Puerto Rico, 2003-2013*

\begin{tabular}{|c|c|c|c|c|c|c|c|c|c|c|c|}
\hline Females & $\frac{\text { Breast }}{\text { No. (\%) }}$ & $\frac{\text { Cervix }}{\text { No. (\%) }}$ & $\begin{array}{c}\begin{array}{c}\text { Colon/ } \\
\text { Rectum }\end{array} \\
\text { No. (\%) }\end{array}$ & $\begin{array}{c}\begin{array}{c}\text { Liver/ } \\
\text { Intra- } \\
\text { hepatic bile } \\
\text { duct }\end{array} \\
\text { No. }(\%)\end{array}$ & $\frac{\begin{array}{c}\text { Lung/ } \\
\text { Bronchus }\end{array}}{\text { No. (\%) }}$ & $\begin{array}{c}\begin{array}{c}\text { Non- } \\
\text { Hodgkin } \\
\text { lymphoma }\end{array} \\
\frac{\text { No. (\%) }}{}\end{array}$ & $\frac{\text { Ovary }}{\text { No. (\%) }}$ & $\frac{\text { Pancreas }}{\text { No. (\%) }}$ & $\frac{\text { Stomach }}{\text { No. (\%) }}$ & $\begin{array}{c}\begin{array}{c}\text { Uterine } \\
\text { corpus }\end{array} \\
\text { No. (\%) }\end{array}$ & $\begin{array}{c}\text { All sites }^{\dagger} \\
\text { No. }(\%)\end{array}$ \\
\hline \multicolumn{12}{|c|}{ Caribbean countries } \\
\hline Anguilla§ & NR & NR & NR & NR & NR & NR & NR & NR & NR & NR & $20(100)$ \\
\hline $\begin{array}{l}\text { Antigua and } \\
\text { Barbuda }^{\S}\end{array}$ & $51(26.1)$ & $15(7.7)$ & $27(13.8)$ & NR & $11(5.6)$ & NR & $16(8.2)$ & NR & $10(5.1)$ & $11(5.6)$ & 195 (100) \\
\hline Aruba ${ }^{\S}$ & $88(24.9)$ & $16(4.5)$ & $28(7.9)$ & $14(4.0)$ & $33(9.3)$ & $12(3.4)$ & $23(6.5)$ & $20(5.6)$ & $16(4.5)$ & $14(3.9)$ & $354(100)$ \\
\hline Bahamas? & $255(28.8)$ & $68(7.7)$ & $79(8.9)$ & $23(2.6)$ & $45(5.1)$ & $28(3.2)$ & $52(5.9)$ & $25(2.8)$ & $31(3.5)$ & $44(5.0)$ & $885(100)$ \\
\hline Barbados? & $280(23.2)$ & $64(5.3)$ & $166(13.7)$ & $21(1.7)$ & $52(4.3)$ & $46(3.8)$ & $46(3.8)$ & $52(4.3)$ & $34(2.8)$ & $77(6.4)$ & $1,207(100)$ \\
\hline Belize ${ }^{\S}$ & $57(14.0)$ & $74(18.2)$ & $28(6.9)$ & $30(7.4)$ & $27(6.6)$ & NR & $8(2.0)$ & $17(4.2)$ & $21(5.2)$ & $33(8.1)$ & $406(100)$ \\
\hline Bermuda** & 53 (19.6) & NR & 45 (16.7) & NR & $38(14.1)$ & $6(2.2)$ & $13(4.8)$ & $15(5.6)$ & $9(3.3)$ & $11(4.1)$ & $270(100)$ \\
\hline $\begin{array}{l}\text { British Virgin } \\
\text { Islands }^{\dagger \dagger}\end{array}$ & $8(19.0)$ & NR & NR & NR & NR & NR & NR & NR & NR & NR & $42(100)$ \\
\hline Cayman Islands ${ }^{\S}$ & $27(29.7)$ & NR & $9(9.9)$ & NR & $9(9.9)$ & NR & NR & NR & NR & NR & $91(100)$ \\
\hline Curacao $§ \S$ & $153(25.7)$ & $27(4.5)$ & $86(14.5)$ & $14(2.4)$ & $37(6.2)$ & $11(1.8)$ & $39(6.6)$ & $24(4.0)$ & $29(4.9)$ & $34(5.7)$ & $595(100)$ \\
\hline Dominicaๆๆ & $52(22.5)$ & $17(7.4)$ & $23(10.0)$ & $10(4.3)$ & $18(7.8)$ & $7(3.0)$ & $8(3.5)$ & $8(3.5)$ & $23(10.0)$ & $9(3.9)$ & $231(100)$ \\
\hline Grenada§ & 71 (19.8) & $37(10.3)$ & $31(8.7)$ & $14(3.9)$ & $17(4.7)$ & $19(5.3)$ & $18(5.0)$ & $18(5.0)$ & $16(4.5)$ & $32(8.9)$ & $358(100)$ \\
\hline Guyana? & 221 (18.7) & $183(15.5)$ & $69(5.8)$ & $43(3.6)$ & $39(3.3)$ & $20(1.7)$ & $74(6.3)$ & $35(3.0)$ & $29(2.5)$ & $101(8.6)$ & $1,181(100)$ \\
\hline Jamaica? & $1,395(21.1)$ & $813(12.3)$ & $653(9.9)$ & $188(2.8)$ & $404(6.1)$ & $201(3.0)$ & $267(4.0)$ & 219 (3.3) & $330(5.0)$ & $414(6.3)$ & $6,618(100)$ \\
\hline Montserrat ${ }^{\text {ๆๆ }}$ & NR & NR & NR & NR & NR & NR & NR & NR & NR & NR & $8(100)$ \\
\hline $\begin{array}{l}\text { St. Kitts and } \\
\text { Nevis }^{\S}\end{array}$ & 29 (20.6) & $12(8.5)$ & $9(6.4)$ & $10(7.1)$ & NR & NR & $10(7.1)$ & $6(4.3)$ & NR & $7(5.0)$ & $141(100)$ \\
\hline St. Lucia§ & 89 (21.2) & $40(9.5)$ & $35(8.3)$ & $12(2.9)$ & $20(4.8)$ & $15(3.6)$ & $21(5.0)$ & $24(5.7)$ & $25(5.9)$ & $16(3.8)$ & $420(100)$ \\
\hline $\begin{array}{l}\text { St. Vincent } \\
\text { and the } \\
\text { Grenadines } \S\end{array}$ & $60(23.4)$ & $36(14.1)$ & $14(5.5)$ & NR & $9(3.5)$ & NR & $10(3.9)$ & $7(2.7)$ & $11(4.3)$ & $23(9.0)$ & $256(100)$ \\
\hline Suriname ${ }^{\S}$ & $136(16.1)$ & $146(17.2)$ & $76(9.0)$ & $43(5.1)$ & $66(7.8)$ & $21(2.5)$ & $55(6.5)$ & $38(4.5)$ & $27(3.2)$ & $22(2.6)$ & $847(100)$ \\
\hline $\begin{array}{c}\text { Trinidad and } \\
\text { Tobago }^{* * *}\end{array}$ & $743(23.2)$ & $346(10.8)$ & $300(9.4)$ & $83(2.6)$ & $138(4.3)$ & $98(3.1)$ & $239(7.5)$ & $174(5.4)$ & $94(2.9)$ & $242(7.6)$ & $3,200(100)$ \\
\hline $\begin{array}{l}\text { Turks and Caicos } \\
\text { Islands**** }\end{array}$ & NR & NR & NR & NR & NR & NR & NR & NR & NR & NR & $17(100)$ \\
\hline $\begin{array}{l}\text { Total for the } \\
\text { Caribbean } \\
\text { countries }\end{array}$ & $3,773(21.8)$ & $1,907(11.0)$ & $1,688(9.7)$ & $526(3.0)$ & $970(5.6)$ & $506(2.9)$ & $906(5.2)$ & $693(4.0)$ & $714(4.1)$ & $1,102(6.4)$ & $17,342(100)$ \\
\hline
\end{tabular}

United States and U.S. Caribbean territories

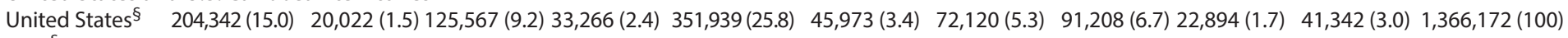

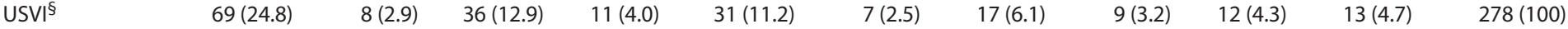

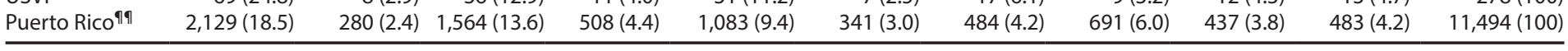

Abbreviations: $N R=$ data not reported for countries with fewer than six cases; USVI = U.S. Virgin Islands.

* Individual countries contributed different 5-year data.

† All sites include top 10 leading cancers as well as other cancers reported by the countries.

§ Data available from 2008 to 2012.

I Data available from 2007 to 2011.

** Data available from 2006 to 2010.

t† Data available from 2004, 2006, and 2008 to 2010.

$\S \S$ Data available from 2003 to 2007.

ๆๆ Data available from 2009 to 2013.

*** Data available from 2005 to 2009.

ASMRs associated with cervical cancers were 2-9 times higher in the Caribbean region, and ASMR for breast cancer was up to two times higher than that in the United States for all but four of the countries. Compared with the United States, prostate cancer ASMR was 2-8 times higher in the Caribbean region. Lung cancer-associated ASMRs were lower for males and females in all of the English- and Dutch-speaking Caribbean compared with those in the United States.

\section{Discussion}

Lung and cervical cancers are important preventable causes of morbidity and mortality in most of the Caribbean countries. Lung cancers can be prevented through primary prevention of exposure to risk factors such as smoking, and cervical cancers can be prevented through human papillomavirus vaccination. The leading causes of cancer deaths in the Caribbean region for both males and females also can be reduced through screening, 
TABLE 2. Age-standardized 5-year mortality rates for the top 10 leading causes of cancer deaths, by sex - 21 countries in the Caribbean region, United States, U.S. Virgin Islands, and Puerto Rico, 2003-2013*

\begin{tabular}{|c|c|c|c|c|c|c|c|c|c|c|c|}
\hline Males & $\begin{array}{l}\text { Colon/ } \\
\text { Rectum }\end{array}$ & Esophagus & Leukemia & $\begin{array}{c}\text { Liver/ } \\
\text { Intra-hepatic } \\
\text { bile duct }\end{array}$ & $\begin{array}{l}\text { Lung/ } \\
\text { Bronchus }\end{array}$ & $\begin{array}{c}\text { Non-Hodgkin } \\
\text { lymphoma }\end{array}$ & $\begin{array}{l}\text { Oral cavity/ } \\
\text { Pharynx }\end{array}$ & Pancreas & Prostate & Stomach & All sites ${ }^{\dagger}$ \\
\hline \multicolumn{12}{|l|}{ Caribbean countries } \\
\hline Anguilla§ & NR & NR & NR & NR & NR & NR & NR & NR & 64.6 & NR & 148.1 \\
\hline $\begin{array}{l}\text { Antigua and } \\
\text { Barbuda }\end{array}$ & 9.5 & 3.4 & NR & 5.6 & 11.8 & 3.4 & 4.3 & NR & 46.8 & 4.1 & 113.7 \\
\hline Aruba ${ }^{\S}$ & 10.1 & 3.4 & 2.6 & 5.5 & 20.6 & 3.7 & 3.3 & 3.2 & 21.6 & 5.7 & 99.3 \\
\hline Bahamas & 14.3 & 5.2 & 4.0 & 4.1 & 16.3 & 2.7 & 3.6 & 5.0 & 44.8 & 8.3 & 142.5 \\
\hline Barbados" & 15.3 & 2.7 & 3.6 & 1.8 & 7.4 & 2.3 & 5.1 & 5.1 & 41.3 & 5.4 & 120.9 \\
\hline Belize $^{\S}$ & 4.9 & 1.6 & 3.0 & 6.8 & 11.8 & 1.9 & 1.3 & 2.1 & 17.7 & 6.0 & 73.3 \\
\hline Bermuda** & 12.6 & 4.1 & 4.3 & 3.8 & 31.9 & 4.1 & 4.3 & 7.7 & 23.3 & 4.7 & 126.4 \\
\hline $\begin{array}{l}\text { British Virgin } \\
\text { Islands }{ }^{\dagger+}\end{array}$ & 15.7 & NR & NR & NR & 12.3 & NR & NR & NR & 25.7 & NR & 113.3 \\
\hline Cayman Islands $§$ & 8.0 & NR & NR & NR & 22.7 & NR & NR & NR & 27.0 & NR & 101.1 \\
\hline Curacao $§ \S$ & 18.1 & 8.5 & 3.2 & 4.2 & 34.0 & 3.6 & 5.1 & 7.9 & 40.6 & 8.4 & 167.6 \\
\hline Dominica ๆ & 8.5 & 3.4 & 2.0 & 5.8 & 14.1 & 4.8 & 4.2 & 10.6 & 62.9 & 13.6 & 157.8 \\
\hline Grenada§ & 11.3 & 8.5 & 2.4 & 3.7 & 14.9 & 11.2 & 6.6 & 6.0 & 60.5 & 8.4 & 167.5 \\
\hline Guyana? & 5.1 & 1.4 & 2.5 & 4.6 & 4.6 & 1.4 & 2.1 & 2.7 & 25.4 & 3.6 & 69.0 \\
\hline Jamaica? & 9.2 & 2.7 & 3.7 & 3.4 & 23.2 & 3.9 & 2.8 & 2.9 & 36.7 & 8.8 & 122.9 \\
\hline Montserrat & NR & NR & NR & NR & NR & NR & NR & NR & 31.7 & NR & 97.6 \\
\hline St. Kitts and Nevis ${ }^{\S}$ & 13.6 & NR & NR & 14.4 & 12.1 & 4.5 & NR & NR & 74.1 & NR & 166.3 \\
\hline St. Lucia§ & 5.5 & 3.8 & 3.8 & 2.1 & 11.3 & 3.4 & 3.7 & 4.5 & 28.1 & 10.2 & 98.8 \\
\hline $\begin{array}{l}\text { St. Vincent and the } \\
\text { Grenadines } §\end{array}$ & 11.2 & 2.5 & 4.8 & 6.9 & 9.7 & 6.2 & 5.9 & 7.9 & 58.9 & 8.3 & 145.5 \\
\hline Suriname $e^{\S}$ & 10.5 & 0.4 & 2.4 & 6.4 & 12.7 & 2.6 & 2.7 & 3.8 & 15.1 & 4.2 & 80.6 \\
\hline $\begin{array}{c}\text { Trinidad and } \\
\text { Tobago*** }\end{array}$ & 13.0 & 2.0 & 3.9 & 2.8 & 16.0 & 3.8 & 3.3 & 6.3 & 39.4 & 5.2 & 119.3 \\
\hline $\begin{array}{l}\text { Turks and Caicos } \\
\text { Islands }\end{array}$ & NR & NR & NR & NR & 5.7 & NR & NR & NR & NR & NR & 50.8 \\
\hline \multicolumn{12}{|c|}{ United States and U.S. Caribbean territories } \\
\hline United States $\S$ & 10.6 & 4.7 & 5.2 & 5.8 & 34.8 & 4.3 & 2.5 & 7.4 & 9.3 & 2.7 & 118.4 \\
\hline USVI§ & 12.3 & 2.5 & 1.8 & 1.6 & 11.9 & 2.5 & 2.3 & 2.8 & 20.1 & 5.5 & 81.4 \\
\hline Puerto Rico $₫$ १ & 11.8 & 3.0 & 3.1 & 6.6 & 11.9 & 2.8 & 3.3 & 4.3 & 12.3 & 3.7 & 88.1 \\
\hline
\end{tabular}

See table footnotes on next page.

\section{Summary}

What is already known about this topic?

Cancer is one of the leading causes of deaths in countries in the Caribbean region; many of the leading causes of cancer deaths in these countries, including breast and cervical cancers, are preventable.

What is added by this report?

The most common causes of cancer deaths among Caribbean males were prostate ( $18.4 \%$ to $47.4 \%$ ) and lung (5.6\% to $24.4 \%$ ) cancers. The most common causes of cancer deaths among Caribbean females for the majority of the countries were breast (14.0\% to $29.7 \%$ ) and cervical (4.5\% to $18.2 \%$ ) cancers.

What are the implications for public health practice?

The leading causes of cancer deaths in the Caribbean region for both males and females can largely be reduced and prevented through many strategies, including primary prevention, early detection, management, and treatment of patients with cancer. Prevention strategies include human papillomavirus vaccination and screening for cervical cancer, screening for breast cancer, and avoiding smoking for lung cancer. early detection, and effective treatment for cervical, breast, and colorectal cancers ( 7 ). Although prostate cancer is the leading cause of cancer mortality among men in the Caribbean, effective screening strategies that result in reduced mortality have not yet emerged globally, highlighting the need for strengthening referral and treatment strategies (8).

The findings in this report are subject to at least five limitations that could result in either under- or overestimation of the presented mortality rates. First, denominator data were not available for the entire study period from any of the countries. Second, cancer-specific mortality rates for the region could not be calculated because there was no single year when all contributing countries submitted data to the Caribbean Public Health Agency. Third, some countries reported approximately 10\% "unknown/missing/invalid" cause of death codes or "non-specific/miscellaneous malignant cancers" as the underlying cause of death, which can compromise the ability to rank the cancer sites accurately. Fourth, results should be interpreted with caution given that age-standardized mortality rates might be unreliable in some countries because of small numbers. Finally, it was not 
TABLE 2 (Continued). Age-standardized 5-year mortality rates for the top 10 leading causes of cancer deaths, by sex -21 countries in the Caribbean region, United States, U.S. Virgin Islands, and Puerto Rico, 2003-2013*

\begin{tabular}{|c|c|c|c|c|c|c|c|c|c|c|c|}
\hline Females & Breast & Cervix & $\begin{array}{l}\text { Colon/ } \\
\text { Rectum }\end{array}$ & $\begin{array}{c}\text { Liver/ } \\
\text { Intra-hepatic } \\
\text { bile duct }\end{array}$ & $\begin{array}{l}\text { Lung/ } \\
\text { Bronchus }\end{array}$ & $\begin{array}{l}\text { Non-Hodgkin } \\
\text { lymphoma }\end{array}$ & Ovary & Pancreas & Stomach & $\begin{array}{l}\text { Uterine } \\
\text { corpus }\end{array}$ & All sites ${ }^{\dagger}$ \\
\hline \multicolumn{12}{|l|}{ Caribbean countries } \\
\hline Anguilla & NR & NR & NR & NR & NR & NR & NR & NR & NR & NR & 50.5 \\
\hline $\begin{array}{l}\text { Antigua and } \\
\text { Barbuda }\end{array}$ & 20.4 & 6.2 & 10.4 & NR & 4.2 & NR & 6.5 & NR & 3.4 & 4.0 & 75.8 \\
\hline Aruba ${ }^{\S}$ & 19.6 & 4.1 & 6.2 & 3.2 & 7.6 & 2.7 & 5.1 & 4.7 & 3.6 & 2.8 & 79.6 \\
\hline Bahamas" & 26.5 & 7.3 & 8.6 & 2.5 & 5.3 & 3.0 & 5.6 & 2.8 & 3.5 & 5.2 & 96.2 \\
\hline Barbados & 23.5 & 5.4 & 12.0 & 1.6 & 3.8 & 3.6 & 4.1 & 4.0 & 1.9 & 6.1 & 94.7 \\
\hline Belize $^{\S}$ & 10.0 & 12.5 & 4.5 & 5.3 & 5.1 & NR & 1.3 & 3.4 & 3.8 & 6.1 & 71.0 \\
\hline Bermuda** & 17.7 & NR & 12.6 & NR & 12.1 & 2.6 & 3.4 & 4.9 & 3.1 & 3.1 & 82.1 \\
\hline $\begin{array}{l}\text { British Virgin } \\
\text { Islands }^{\dagger+}\end{array}$ & 12.7 & NR & NR & NR & NR & NR & NR & NR & NR & NR & 83.0 \\
\hline Cayman Islands ${ }^{\S}$ & 21.7 & NR & 6.4 & NR & 7.2 & NR & NR & NR & NR & NR & 70.6 \\
\hline Curacao ${ }^{\S \S}$ & 27.3 & 5.0 & 13.9 & 2.2 & 5.9 & 1.9 & 6.4 & 4.0 & 4.3 & 5.6 & 100.7 \\
\hline 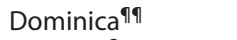 & 25.0 & 9.8 & 9.1 & 4.5 & 6.5 & 3.1 & 4.0 & 2.7 & 8.0 & 4.5 & 101.0 \\
\hline Grenada ${ }^{\S}$ & 25.5 & 12.0 & 7.5 & 4.1 & 5.1 & 8.8 & 6.2 & 5.1 & 4.4 & 9.5 & 114.2 \\
\hline Guyana? & 11.6 & 9.7 & 3.7 & 2.4 & 2.0 & 1.0 & 4.0 & 2.1 & 1.6 & 5.6 & 63.1 \\
\hline Jamaicaף & 19.5 & 12.1 & 8.1 & 2.7 & 5.5 & 2.9 & 3.8 & 2.8 & 4.1 & 5.7 & 90.5 \\
\hline Montserrat & NR & NR & NR & NR & NR & NR & NR & NR & NR & NR & 32.1 \\
\hline St. Kitts and Nevis ${ }^{\S}$ & 24.7 & 12.3 & 8.3 & 10.7 & NR & NR & 10.6 & 4.4 & NR & 6.1 & 123.3 \\
\hline St. Lucia ${ }^{\S}$ & 17.8 & 7.7 & 7.1 & 2.1 & 3.9 & 3.0 & 4.3 & 4.2 & 4.1 & 2.8 & 79.6 \\
\hline $\begin{array}{l}\text { St. Vincent and the } \\
\text { Grenadines } \S\end{array}$ & 22.9 & 15.5 & 5.5 & NR & 2.8 & NR & 3.8 & 2.3 & 3.6 & 8.0 & 96.6 \\
\hline Suriname $e^{\S}$ & 10.6 & 11.0 & 5.9 & 3.3 & 5.1 & 1.6 & 4.1 & 3.0 & 2.0 & 1.7 & 64.1 \\
\hline $\begin{array}{l}\text { Trinidad and } \\
\text { Tobago }\end{array}$ & 23.4 & 10.8 & 8.9 & 2.5 & 4.1 & 3.1 & 7.4 & 5.0 & 2.6 & 7.6 & 97.8 \\
\hline $\begin{array}{l}\text { Turks and Caicos } \\
\text { Islands"** }\end{array}$ & NR & NR & NR & NR & NR & NR & NR & NR & NR & NR & 41.7 \\
\hline \multicolumn{12}{|c|}{ United States and U.S. Caribbean territories } \\
\hline United States ${ }^{\S}$ & 14.1 & 1.7 & 7.3 & 2.1 & 22.6 & 2.5 & 4.8 & 5.4 & 1.4 & 2.8 & 87.2 \\
\hline USVI§ & 13.3 & 1.7 & 6.3 & 1.7 & 5.3 & 1.2 & 3.2 & 1.5 & 2.0 & 2.4 & 49.5 \\
\hline Puerto Rico ๆๆ & 12.2 & 1.9 & 7.2 & 2.3 & 5.0 & 1.7 & 2.6 & 3.1 & 2.0 & 2.7 & 58.1 \\
\hline
\end{tabular}

Abbreviations: $\mathrm{NR}=$ data not reported for countries with fewer than six cases; USVI = U.S. Virgin Islands.

* Individual countries contributed different 5-years of data. Rates are per 100,000 and age-standardized to the Segi World Standard population (million; 18 age groups); age-standardized mortality rates for countries with small number of deaths may be unreliable and should be interpreted with caution.

+ All sites include top 10 leading cancers as well as other cancers reported by the countries.

$\S$ Data available from 2008 to 2012.

" Data available from 2007 to 2011.

** Data available from 2006 to 2010.

†† Data available from 2004, 2006, and 2008 to 2010.

$\S \S$ Data available from 2003 to 2007.

१ศ Data available from 2009 to 2013.

*** Data available from 2005 to 2009.

possible to account for the variability regarding the inclusion and exclusion of nonresident deaths in mortality statistics or of deaths of residents that occurred abroad.

Despite the limitations, these findings identify cancers that are leading causes of death among men and women in the Caribbean region; underscore the importance of establishing reliable cancer surveillance systems in the region to understand and assess the prevalence of cancer, and provide a foundation for cancer control plans and effective public health interventions; and might inform the strengthening of cancer prevention priorities and programs in the Caribbean including US territories such as USVI and Puerto Rico.

\section{Acknowledgments}

The 21 countries of the Caribbean Public Health Agency; the U.S. Virgin Islands; Puerto Rico; National Center for Health Statistics, CDC; Mathieu Laversanne, the International Agency for Research on Cancer, World Health Organization.

\footnotetext{
${ }^{1}$ National Center for Chronic Disease Prevention and Health Promotion, CDC

${ }^{2}$ United States Public Health Service; ${ }^{3}$ The Caribbean Public Health Agency, Port of Spain, Trinidad and Tobago; ${ }^{4}$ The North American Association of Central Cancer Registries, Springfield, Illinois; ${ }^{5}$ National Cancer Institute, Rockville, Maryland; 'International Agency for Research on Cancer, World Health Organization, Lyon, France; ${ }^{7}$ Pan American Health Organization, World Health Organization, Washington, D.C.
}

Corresponding author: Hilda Razzaghi, Hrazzaghi@cdc.gov, 770-488-6518. 


\section{References}

1. International Agency for Research on Cancer. World cancer report, 2014. Lyon, France: World Health Organization, International Agency for Research on Cancer; 2014. http://publications.iarc.fr/Non-SeriesPublications/World-Cancer-Reports/World-Cancer-Report-2014

2. International Agency for Research on Cancer. Estimated cancer incidence, mortality and prevalence worldwide in 2012. Lyon, France: World Health Organization, International Agency for Research on Cancer; 2012. http:// globocan.iarc.fr/Pages/fact_sheets_cancer.aspx

3. International Agency for Research on Cancer. Globocan 2012. Lyon, France: World Health Organization, International Agency for Research on Cancer; 2012. http://globocan.iarc.fr/Default.aspx

4. Surveillance, Epidemiology, and End Results Program. SEER*Stat software version 8.2.1. Rockville, MD: US Department of Health and Human Services, National Institute of Health, National Cancer Institute, Surveillance, Epidemiology, and End Results Program; 2016. https://seer.cancer.gov/seerstat
5. Segi M. Cancer mortality for selected sites in 24 countries (1950-57). Sedari, Japan: Department of Public Health, Tohoku University of Medicine; 1960.

6. Bray F, Guilloux A, Sankila R, Parkin DM. Practical implications of imposing a new world standard population. Cancer Causes Control 2002;13:175-82. http://dx.doi.org/10.1023/A:1014344519276

7. Gelband H, Sankaranarayanan R, Gauvreau CL, et al. Costs, affordability, and feasibility of an essential package of cancer control interventions in low-income and middle-income countries: key messages from Disease Control Priorities, 3rd edition. Lancet 2016;387:2033-44.

8. Gelband H, Jha P, Sankaranarayanan R, Horton S, eds. Disease control priorities. In: Cancer. 3rd ed, vol 3. Washington, DC: World Bank Group; 2015. http://dcp-3.org/cancer 